\title{
Exploitation and Abuse of Children in
}

\section{“Entrepreneurial” Purposes}

\author{
Goran Kutnjak, Matija Radović \\ Faculty of Economics Rijeka, Rijeka, Croatia \\ Diana Blašković \\ Pharmacy “Ilona Lenac”, Labin, Croatia
}

\begin{abstract}
The society of today often likes to brand itself as modern, advanced, civilized, or a society of positive changes. However, it is a fact that the world is confronted with huge contradictions that oppose such qualifications. Obviously, one of the most striking and almost unbelievable realities tells us about inhumane and uncivilized actions of child exploitation in "entrepreneurial” purposes in the widest range of exploitation and abuse. Current period of economic crisis tells us even more about the rising crisis of moral, which is, in statistical terms, confirmed by a rising number of exploited children in a global framework, and even in some national frameworks as well. With that, some positive results about the diminishing number of exploited children are devaluated. The question is what are the "limits" of such behavior of groups, organizations, and individuals whose behavior is, obviously, tolerated in the frameworks of certain national economies. Does this behavior have clarity as a part of modern society? Or, even more severe, for how long can we as a society close our eyes in front of such facts? Do we even have the right? In this paper, the authors strive towards focusing and objectifying the global problem of exploitation and abuse of children in "entrepreneurial” purposes, primarily with the purpose of updating all parts of the society of this paradox and the need of raising the awareness and teaching all relevant factors-from institutions to individuals, with the purpose of resolving and more neutralize the equivalents of this uncivilized and non-entrepreneurial "phenomenon", as well as approaching the same in the framework of different actions with broadest measures possible and with all disposable assets.
\end{abstract}

Keywords: entrepreneurship, children, exploitation, abuse, forms of exploitation

\section{Introduction}

Modern society, and entrepreneurship with it, exists on human principles and very stable criteria of doing business, which are backed up in the law legislative. Normally, when we talk entrepreneurship, it is well known who, how, under what conditions, and when can perform an entrepreneurial activity, and who in the sense of an

Goran Kutnjak, Associate Professor, Business administration, Faculty of Economics Rijeka.

Matija Radović, Assistant, Business administration, Faculty of Economics Rijeka.

Diana Blašković, Ph.D. candidate, Business administration, Pharmacy “Ilona Lenac”.

Correspondence concerning this article should be addressed to Goran Kutnjak, Faculty of Economics Rijeka, Ivana Filipovića 4, 51000 Rijeka, Croatia. E-mail: goran.kutnjak@efri.hr. 
employee can be employed, that is which are the limits going from the normal and socially acceptable work into exploitation and abuse of children.

Regarding this situation and its non-sustainability we are constantly warned by the International Labor Organization (ILO), which not long ago, on the International Day against Child Labor in the world, published a data about the current "employment” (labor) of 218 million minors, of which almost half (around 100 million) are little girls less than 12 years old (Retrieved from http://www.facebook.com/note.php?note_id=164228776930672) and they are primarily forced into doing hard physical labor. De facto more than half of the world population of children is forced into doing all sorts of different labor.

Overall, the irony is, despite some positive movements in the world, the global economic crisis is endangering the progress towards reducing child labor (more than 218 million children forced into labor). A new report of the International Labor Organization warns (Retrieved from http://www.voanews.com/croatian/news/Meunarodna-organizacija-rada-123760474.html) about the fact that a very high number of children are still being forced into labor, what sometimes includes even the most dangerous jobs. Devastating statistics say:

- 218 million children (aged from five to 14 years old) is forced into labor around the world, of which 122 million are from Asia;

- 132 million children works on dangerous jobs in very damaging and dangerous conditions;

- 1.2 million children are victims of child slavery, including the newborns;

- 300,000 children carry weapons and fight wars around the world;

- 73 million employed children are less than 10 years old;

- every year 22,000 children die as a consequence of accidents at work (Škes, 2011).

According to United Nations' data, 700,000 women, children, and men become victims of human trafficking every year. It is estimated that today 27 million people are enslaved, of which eight million are children. According to the estimates of the ILO in the year 2000, 1.8 million children were used in the sex industry. United Nations Office on Drugs and Crime (UNODC) claims that from the total number of human trafficking victims, 48\% are children (Retrieved from http://www.mup.rh/31.aspx).

\section{Experiences of Exploitive Labor of Children or Their Abuse of the Worlds and Croatia}

According to ILOs report every day, somewhere in the world, a child forced into labor gets into an accident or suffers an injury in work, gets a disease or suffers a psychological trauma. The most dangerous jobs for children are done in the primary business sector-agriculture, fishing, domestic services, mining and quarry, as well as on the streets and in the service sector. The report talks about many brutal and dangerous conditions in which children are working, and which endanger their health, as well as their moral and psychological development. There are many kinds of exploitation: physical, psychological, sexual, carrying excessive weight and exposure to chemicals, long work days, repetitive tasks, and labor in isolation. It is mentioned that children need stimulation - intellectual and social, and if they are isolated and given (forced onto) mind numbing jobs which are always the same, that will suppress their development.

Children are being employed in hazardous work not only in developing countries, but everywhere in the 
world, even in the industrially developed countries. Proof from the United States and Europe shows that boys and girls are very prone to accidents at work. According to the data from the report, most children working in hazardous work are from Asia and the Pacific area. However, that problem is most common in the sub-Saharan region, where the frequency of child labor in hazardous work is double than in Asia or Latin America. Data which refer to African children show that $15 \%$ of all African children are working in hard and dangerous conditions, especially because of the job description (mostly in agriculture, which has plenty of potentially dangerous jobs). Generally, most people in sub-Saharan Africa are employed in agriculture, a lot more than in Asia or Latin America (ILO: Forcing children into labor is still a huge issue).

Of the worst form of labor witness the information from Philippines where in 2001, four million children aged five to 17 were employed, of which 2.4 million in hazardous work, and of those more than 18,000 in mines and quarries. Half of these children are aged between 10 and 14. Children within these mines earn one dollar a day for eight to 12 hours of labor, through what they severely damage their health. Skin disease, constant cough, cold and fever are a frequent occurrence (Retrieved from http://dalje.com/hr-hrvatska/na-rad-prisiljeno-218-milijuna-djece/264932).

Regardless of this bleak picture ILO points out that during the last decade we have had a significant improvement: almost a third of the girls and a fourth of the boys are no longer working in the most gruesome forms of child labor exploitation, and that the total number of children aged five to 17, who were engaged in potentially hazardous work and work conditions, was declined from 2004 till 2008. However, unfortunately, the number of children aged 15 to 17 increased by 20\% during the same period: from 52 million to 62 million (ILO: Forcing children into labor is still a huge issue). Even though, the public embraces the idea of reducing child labor in the world, there are still indications that the world economic and financial crisis is endangering that process. That is why this is the time which will confirm or, maybe even deny how much are certain governments, as well as the world as a social community, willing to implement the commitments related to this question, or better said this urgent worldwide problem. Well, certain suspicions speak in favor of the "thesis" that this period of economic crisis will benefit from and justify the "need" of employing child labor within certain national economies, so that we can more easily overcome all the down sides and consequences of the crisis. The fact is that the crisis, especially in the undeveloped countries, drastically worsened the state within poor families, namely, with those which have more children, which have traditionally given advantage to boys in education, and as a result of which more and more girls are forced into labor. Girls are additionally threatened because they regularly work in the households of other families where they are, while hidden from the public eye, often exploited. Given all their obligations on one side, and the lack of knowledge and education on the other side, chances of leaving the vicious circle of poverty are almost non-existent.

The Croatian Parliament passed the law which confirms the ILO Convention on the Worst Forms of Child Labor (no.128): Parallel with the commemoration of the World Day against Child Labor this year, the Croatian Parliament has presented the report of the Office of Ombudsman for Children which states that in the last five years they have recorded 150 cases of child exploitation in entrepreneurial purposes, which is about $5 \%$ of all reported child abuse cases in that period. One of the major problems stated in the report is minors working night shifts 
the report of the state inspectorate in 2011, in the surveillance of 30 employers, there has been a discovery of illegalities towards 32 minors, and 66 violations of regulations on employment, which is a worrying trend of exploitation of children and minors. The previous year, the Inspectorate found 55 violations towards 27 minors.

The highest rate of illegalities was found in catering, trade, bakery, tourism, construction, and craft-service activities. Sixteen boys (minors) were found working as waiters, three as assistant chefs, one as an assistant baker, seven girls (also minors) were found working as cashiers, one boy as an assistant construction worker, one in agriculture, and three minors working in cleaning. The spectrum of violating the conditions of work of minors is very wide: There were cases of making incomplete employment contracts, employers were employing minors without a parent/guardian consent, they were withheld the right to a daily and weekly rest, there was no record of working hours, they were not giving them the mandatory pension and health insurance. Croatian employers violated the law further with employing children less than 15 years old, on jobs which can endanger their safety, health, morality, or development, they were not sent on prior medical reviews, they were forced to work hours longer than permitted by law. Both children and minors were working months without pay, foreign minors were employed without a work permit, and all that while they were working for a pay which is less than minimum wage. Against the employers who were proved to have been violating the rights of minors, 30 indictments were filed, in 13 cases the work of minors and children was banned, and in six cases the employers were given a prohibition to perform activities until they eliminate the detected omissions (Retrieved from http://www.civilnodrustvo.hr/index.php?id=74\&tx_ttnews\%5Btt_news\%5D=2120\&cHash=8402d5061d0e72c 40f6af71069af). Regarding human trafficking, Republic of Croatia has included itself in the action of suppressing human trafficking in 2002, when in May of the same year, a National committee for suppressing human trafficking was formed in which the representatives of relevant government bodies, non-government organizations, and the media were named. Since then a national referral system for helping and protecting unidentified victims of human trafficking was formed. Until now 103 victims of human trafficking were identified, within whose cases a missing person reports were recorded, that would ultimately determine that the person was an "object” of trade. In these cases, the person was already, oftentimes in an indirect way, drawn into the human trafficking chain, and the perpetrators, through establishing control mechanisms to prevent escaping, deprived them from their freedom to move or make contact with friends and family.

\section{Worst Forms of Child Labor}

Millions of boys and girls worldwide are employed in a way that more than half of them are forced into the worst sorts of child labor, such as working in dangerous surroundings, slavery or other forms of forced labor, illegal activities (smuggling, prostitution), as well as participating in armed conflicts. Those children are denied proper education, health, free time, all that with violating their fundamental human rights and freedom. When we talk of the worst forms of child labor same implies that:

- all types of slavery or practices similar to slavery, like human trafficking, debt bondage and serfdom as well as mandatory or forced labor, including forced or mandatory recruitment of children for their participation in armed conflicts;

- usage, procurement or offering a child for prostitution, making of pornographic materials, or pornographic performances; 
- usage, procurement or offering a child for illegal activities, especially for drug manufacturing and trade, in such way defined by the corresponding international treaty;

- labor which would, due to its nature and circumstances in which it is being performed, could harm the child's safety, health, and morality.

In its nature, the given forms of child labor have their sub levels, or better said shades, within which we can define all the brutality, cruelty, and inhumanness of such treatment of children—not just because of treating them like "subjects" of labor, but more like unimportant and irrelevant "objects", like in the case of, for example, kidnapping with the purpose of organ trafficking or illegal adoption. Regarding the "nature" of children exploitation some subtypes are known:

(1) Labor exploitation-Children and other victims of human trafficking are used for work on plantations, mines, factories, and manufacturing. Working conditions are always life-threatening, for example, working with dangerous chemicals or working with dangerous machinery. These children are mostly held under constant supervision and in isolation, and mostly, due to unfamiliarity with the language, they are not able to inform the government officials;

(2) House work-It is estimated that most children (primarily girls) are used for house work. Both parents and children are often lured in by false promises of education or a well-paid job. Once a child enters the human trafficking chain, he/she goes under the control of their dealer and they become dependent on the them;

(3) Sexual abuse-Children, especially girls who become victims of trade, are used for labor in the sex industry. They are put into labor in brothels, massage parlors, on the street, and are also used for making pornographic and pedophile material;

(4) Child soldiers-It is estimated that child soldiers were used in more than 30 armed conflicts in almost every part of the world. Some children are used in armed conflicts resulting from poverty or abuse, while some were forcibly recruited or kidnapped. They are being used as messengers, carriers, chefs or for sexual purposes, and as warriors as well. Some children are even forced to killing their parents and/or other family member. A growing trend in Somalia is video games. They are used to entertain the youth and in a way give them other hobbies so they do not "get bored" and join rebel forces (Retrieved from http://www.guardian.co.uk/world/2012/may/04/somalia-video-game-boom-al-shabaab).

(5) Illegal adoptions-A growing demand for adoption is benefiting the human trafficking in babies and small children. Sometimes mothers from developing countries sell their children. It is also not a rare occurrence that a newborn is kidnapped, and the mother to be told the newborn was stillborn.

(6) Sports-Boys, victims of human trafficking, are often sold to the Middle East as camel jockeys. Camel racing is a very lucrative sport, and children are wanted because of their small size. Using children as camel jockeys is very dangerous and it can result in serious injuries and even death. Boys who lose the race are beaten, are deprived of pay and food, and are as well psychically and mentally abused;

(7) Mendicancy_-Besides sexual exploitation, mendicancy or begging is one of most common forms of children exploitation — victims of human trafficking. In some cases, children are deliberately mutilated in order to arouse pity and compassion, and with that raise more money;

(8) Organ trafficking - With human trafficking, a human being becomes merchandise which is being traded. When it is used up and no longer applicable in any other way, dealers than must recycle the human body and 
remove its organs. Human trafficking in the purpose of organ trafficking is very hard to track or detect (Retrieved from http://www.mup.rh/31.aspx).

\section{Human Trafficking and Risk Factors}

The term "trafficking" or human trafficking is a commercial sale of human beings, which most often results in sexual exploitation (For example, prostitution or forced marriage) or forced labor without pay; including physical abuse, compulsion, intimidation, sexual abuse, fraud, and other forms of coercion, as well as terrorizing and intimidating in order to gain, attract, capture and transport people for further exploitation. That way people are turned into merchandise, like any other merchandise on the market, merchandise with its value which will, after an assessment, be paid, an unfair pay for a human life which is priceless. Human life is worth more than all the goods of this world, and it is being sold as third-rate goods with an expiration date (Gluić, 2012).

Trafficking is very much different than people smuggling in a way that in the case of smuggling, people independently and willingly choose this and are seeking for human smugglers for a certain amount. After the job is done, when they arrive at their destination they are either free or continue to work for "nickels and dimes" for their smugglers until they pay off their debt. In contrast, victims of trafficking become slaves, and the working conditions in which they are forced to work in are inhumane. The victims are deprived of basic human rights, especially those which, according to the Universal Declaration of Human Rights, relate to the right to a life, freedom and personal safety. Their life is doomed, along with false promises and physical abuse. Some victims of trafficking live in complete isolation. People traded most often come from poorer regions of the world, where their opportunities are limited and the social relations are very sensitive, for example, in the ex-Yugoslavian (ex-yu) region, after the armed clashes in BIH and Kosovo. Victims are not only from poor families. Their social and financial status are different, but their fate is similar.

As a course of events listed above, it is obvious that this "treatment" of people, most often children, will leave certain severe consequences on the victim. Every trafficking victim, during the whole process is exposed to trauma and stress caused by the physical, mental and sexual abuse. They are abused and exploited by every perpetrator: dealers, “employers", pimps and customers, and the consequences are manifested into two aspects:

(1) Emotional consequences - children, trafficking victims feel shame, guilt and have low self-esteem. They feel betrayed, especially if the perpetrator is someone they trusted. These factors, as well as the experience itself, can cause nightmares, insomnia, the feel of hopelessness, and depression, and can even lead to suicide;

(2) Physical consequences — children who are victims of human trafficking in purpose of sexual exploitation are in great danger of sexually transmitted diseases (STDs), including HIV and AIDS. Many women, girls, and children are used for household work, for work in factories, for mendicancy, are also often sexually abused, raped and beaten, what surely leaves lasting effects on their health.

Human trafficking is one of the most severe global problems of today. It is the fastest growing criminal industry in the world as well as it is the most profitable illegal industry, right below drug trafficking. Total annual revenue of human trafficking is estimated to be $\$ 31.6$ billion. In the last few years human trafficking, particularly of women and children in purpose of sexual exploitation, has reached alarming rates. In Western Europe, a couple hundred thousand people are sold annually. Trafficking victims are men, women, and children. Men are most often victims of forced labor, women and children are used for prostitution, and children for mendicancy and are 
also being sold to families with no children. All men, women, and children, are used for organ trafficking.

In the highest rate, victims of trafficking are women, to whom the potential kidnappers in search of new "merchandise”, promise a good and well-paid job and a chance for further education. Most often they end up in the hell and nothingness of the criminal underworld, forced to through prostitution, make sure to see the next day of their lives. To their personal slaveholder they ensure a profit, while for themselves bare necessities for surviving. Thousands of children, mostly from Asia, Africa, and South America are sold annually into the global sex trade. Oftentimes these are kidnapped children, children without families or the ones sold by their parents. If somehow they do not succeed in fleeing from their kidnappers, they are condemned into a lifetime of slavery and sexual abuse. Simply put - these children lose their right to live their lives with dignity and worthy of a human being. Behind appealing ads for well-paid jobs abroad offered by different "agencies”, often hides organized crime. Victims are deceived and taken from their place of residence abroad, stripped of their documents and forced into doing various jobs.

Although there are common risk factors that a woman, a child or a man could become a victim of human trafficking, the most common risk factors are, however, more specific for women and children (Retrieved from http://www.mup.rh/31.aspx):

- Poverty — poverty puts children in a very vulnerable position and poor children are very high on the list of potential trafficking victims. Dealers offer the possibility of employment outside their country and the extremely poor families, seduced by such promises, oftentimes send their children to work outside their reach.

- Inequality of women, teenage girls and children in a society-legal and social inequality of women, teenage girls and children are very "fertile ground" for trafficking. In places where women, teenage girls, and children are reduced to an "object" and/or "merchandise", there is a suitable climate and environment for trading in women, teenage girls, and children. They are often abused and exploited even in their own families. In such situations the promise of a dealer seems like a chance to escape the abuse and violence in their families. To many of them, migration and/or employment beyond the reach of their society does not represent only a financial decision, but rather an aspiration for finding their own personal freedom, better living conditions, or a way to support their families.

- Not attending school—children who do not attend school can easily become victims of trafficking. It is estimated that around 121 million children worldwide are not attending school, most of which are girls. Attending school is a key element in fight against human trafficking, because education gives children better and greater opportunities of employment and overall a better chance at life.

- Children without families and/or guardians — children without families and/or guardians, living in an orphanage. As the most neglected children they are very high on the potential trafficking victim ladder. Orphans and children separated or taken from their families because of poverty, armed conflicts, violence, or migrations can live in very unstable surroundings, without guardians. All of these factors increase the possibility of becoming victims of human trafficking.

- Not registering children after birth—children not registered into the parish register of the state are also in great danger of becoming victims of human trafficking. About $40 \%$ of children worldwide are not registered when born. Those children have no legal identity and that makes it easier for dealers to hide them, transfer them to other countries and eventually sell them. 
- Humanitarian crisis and armed conflicts_-during a conflict, armed forces can kidnap children and force them to participate in the armed conflict as child soldiers. These children can also be sexually abused. Armed conflicts contribute to easier crossing the border between conflicting parties, and in such way make the job easier to human dealers. It has been proven that an increase in sexual abuse of children in post-conflict zones is closely connected with the coming of peace forces.

- All growing requests in the sex industry and the need for cheap labor-trafficking and the huge demand for cheap labor and sexual services are closely connected. The result of such demands is the exploitation of children in factories and manufacturing as well as in sexual perversions.

\section{Manifestations of World and Croatian Efforts in the Fight Against Child Labor}

World Day against Child Labor is held worldwide in more than 60 countries. For this occasion, during this year's World Day against Child Labor the ILO has called out and urged nations to take emergency measures for stopping the current practice. On the same day the ILO has held a special session in Geneva, due to the fact that the World Day Against Child Labor coincides with the 10th anniversary of the Convention 182nd about the elimination of the hardest forms of child labor. The Convention about the worst forms of child labor exploitation has been ratified by 169 countries of the world (another 14 are missing in order to have a unanimous vote), and the same binds all the members to, taking into account the importance of education in the fight against child exploitation and abuse, to take effective and time-bound measures in order to:

- stop engaging children in the worst forms of child labor;

- ensure the needed and adequate direct help in order to remove children from the worst forms of child labor and their rehabilitation and integration into society;

- provide access to free basic education and, wherever it is possible and appropriate, professional training for every child "taken from" the worst forms of child labor;

- identify the especially endangered children and contact them directly;

- take into account special setting in which are little girls.

Commemorating the World Day against Child Labor is being done since 2002, as well as the ILO Convention 182 about the worst forms of child labor, which has been confirmed by Croatian Parliament in 2001. It is held every year on June 12th in the ILO. The goal is raising the awareness and initiating activities around the world against child labor and employment of children, seeking support of certain governments, social partners, individuals, as well as the media in the campaign against every form of child exploitation and abuse (Škes, 2011).

\section{Conclusions}

Every society has, that is-it should have its values. By many, there is no greater value than children, no matter where they live and no matter how rich or poor the societies they live in are. On the other hand, one of the greatest values of the modern society is the right to work, the right to create, the right to do business, the right to a salary, the right to a decent life. However, when those two values are in a collision, or rather when they both start to lose sense and its true value, it means that the society itself is coping with big problems and that the value system is absolutely reduced to a new low, or simply, it has been degraded. And precisely, this is 
happening, and all around us, to a higher or a lesser extent, to all of us. Namely, there is around 218 million children worldwide that are being exploited or abused for all sorts of "entrepreneurial" and "economic" interests of different groups, clusters, or individuals, and the forms of their abuse and exploitation are various: from forced labor, forced prostitution, kidnapping children for adoption, organ trafficking etc.. The core meaning is the same: to create economic benefits (profit) in the most brutal, often the worst and most criminal way-by trafficking people, mostly women and children. The Machiavelli rule, which states that "the end justifies the means", in this case, has proven its "rhetoricalness", brutality and roughness. It is given to the consciousness and conscience of humanity and such "entrepreneurs".

Certain countries, in the most repressive way, are fighting against all sorts of exploitation and abuse of men, women, and children, even in the form of their exploitation in "economic" goals, and they have, about the resolving this uncivilized and supremely inhumane question and problem, integrated themselves in protecting the interests and rights of the people, and resolving this paradox. But, in nature, despite all efforts, in the period of current economic crisis, it indicates the increase of the number of many different forms of child exploitation and abuse cases; but what is not and cannot be an excuse or justification for this incrimination. In contrast, building a legitimacy of a civilized, humane society not only at the world level, but at the level of a national environment separately, and even at the level of their economies, is absolutely hypocritical. Because, if this paradox is approached with doubts of its scale, or failure to act in an intensive way with purpose of its settlement, or even closing our eyes in front of this alarming and extremely worrying data and facts, are we ourselves worthy of our lives? In the context of all that is stated above, do we have the right to ask ourselves: are these children and labor (entrepreneurship) one of the most significant values of our community, and society as a whole? Or are we again lying to ourselves?

\section{References}

165 cases of illegally employed children. (2012). Retrieved May 16th, 2012, from http://www.moj-posao.net/Vijest/60486/U-165-slucajeva-protuzakonito-zaposljavanja-djeca/2/

218 million children forced into labor. (2012). Retrieved May 16th, 2012, Retrieved from http://dalje.com/hr-hrvatska/na-rad-prisiljeno-218-milijuna-djece/264932

Children exploitation. (2012). Retrieved $\quad$ February $\quad 10$ th, $\quad 2012$, from http://www.civilnodrustvo.hr/index.php?id=74\&tx_ttnews\%5Btt_news \%5D=2120\&cHash=8402d5061d0e72c40f6af71069a $\mathrm{f}$

Gluić, K. (2012). Human trafficking does not happen to someone else. Retrieved August 10th, 2012, from http://www.nestali.hr/default.aspx?id=54

Human trafficking — how not to become a victim. (2012). Retrieved February 10th, 2012 from: http://www.mup.rh/31.aspx

Inappropriate labor of minors and children in the world. (2012). Retrieved August 10th, 2012, from http://www.facebook.com/note.php?note_id=164228776930672

International labor organization: forcing children into labor still a huge problem. (2012). Retrieved January 7th, from http://www.voanews.com/croatian/news/Meunarodna-organizacija-rada-123760474.html

Škes, M. (2011). World day against children labor. Retrieved June 12th, 2011, from http://www.stampar.hr/SvjetskiDanBorbeProtivDjecjeg 